\title{
A STUDY CASE ON CSR AND MANAGERIAL CULTURE IN THE EASTERN ROMANIAN PRIVATE BUSINESS
}

\author{
Roxana Mironescu \\ "Vasile Alecsandri" University of Bacau \\ roxy_mironescu58@yahoo.com
}

\begin{abstract}
The Corporate Social Responsibility (CSR) is a prerequisite for business growth, through innovation and business opportunities providing, in order to make the difference between companies, in the high competitive environment. In our view, the CSR must be integrated and developed inside the company strategy, as its basic set of moral values and principles that reflect the company goals. In this scientific approach, we have explained the concept of Social Responsibility both in terms of theory and as an analysis support for practical issues, in some eastern Romanian companies. The paper is oriented for achieving two main goals: to determine the main Social Responsibility actions made by the companies and to demonstrate the importance of their implementation; to explore the impact of the CSR activities on an expected advantageous position of these companies on their markets. Considered as a direct beneficiary of the community where it belongs, the company returns a part of its success to the community through its active participation in the critical general problems. A company that does not respect the environment, the community, its employees or the ethical principles, will lose credibility and will move away customers and suppliers.
\end{abstract}

\section{Keywords}

Corporate Social Responsibility; competitive advantage; managerial culture; economic and social efficiency; ethical principles

\section{JEL Classification}

M10

\section{Introduction.}

Starting with the ' 80 s to the present, the issue of the ethical behavior in the business world was significantly intensified under the pressure of certain laws, national regulations, European regulations, international regulations and under the powerful influence of the public opinion and the media. Although there are no studies to refute/confirm this aspect, the ethical/unethical business conduct are determined by the manager and his management team.

Creating this manifestation of business ethics, which aimed to improve the climate of business ethics has been implemented in organizations through various instruments such as codes of ethics, ethics committees and trainings in ethical topics and the establishment of associations operating in this area.

Bad practices of business can produce enormous harm to individuals, communities and the environment. Helping us to better understand the causes and consequences of these harmful practices, business ethics seeks to improve the human condition. The shareholders' demands businesses to be ethical, to become more complex. Business Ethics provides means to better appreciate and understand these challenges, so the companies can respond more effectively to the ethical expectations.

Few European or from the other parts of the world people have received a formal education in terms of the business ethics. Business Ethics helps to the ethical decision making, providing executives with the necessary knowledge and tools enabling them 
to correctly identify, diagnose, analyze and provide solutions to the problems and the ethical dilemmas they face.

Ethical offenses continue to occur in business. For example, Ferrel et al. cites a study (Ferrel et al, 2000) which shows that $48 \%$ of employees in the United States admit to an unethical or an illegal guilty. Business Ethics provides a new way to look at the reasons behind these actions, as well as the ways these problems could be solved by managers, people of the law or others, interested in improving business ethics.

Business Ethics provides the capabilities and skills to assess the benefits and problems associated with different ways to lead business ethics inside an organization.

Business Ethics gives us knowledge that go beyond certain traditional schemes of business study, business have to face with some of the most important questions raised by the society. It also gives us the knowledge and skills not only help in the field of business, but also helps us to understand modern societies in a systematic way, it gives us the opportunity to approach some life situations beyond the classroom or the office.

Promoting the appropriate ethical behavior, both from managers and the subordinates, it has a great importance for the final results that impact the entire organization.

\section{The Corporate Social Responsibility, a conceptual approach, as a component of business ethics.}

The responsibility is defined in the dictionary of the Romanian Language (DEX) as a conscious attitude, a sense of responsibility towards the social obligations or a task, a liability someone assumes. Howard R. Bowen, considered by Archie B. Carroll as the father of the corporate social responsibility is the first reference to the term CSR (Corporate Social Responsibility) [Bowen, H. R. 1953]. He argues that a company is obliged to take those decisions or to follow those lines of action which are desirable in terms of goals and values of the society. Bowen argues that the acceptance of the concept of social responsibility has a double motivation. Businessmen must behave like responsible moral agents towards the society. [Frunză, S., 2011].

The European Commission (http://www.ces.ro/newlib/studii-ces/STUDIULResponsabilitate-Sociala-Companii.pdf accessed at: 02/24/2016) by a press communicate 347/2002 defines the Corporate Social Responsibility as a contribution to the sustainable development of the enterprise: "the sustainable development seeks to meet the needs and aspirations of the present without compromising the ability to accomplish those of the future" (World Business Council for sustainable development - www.wbcds.org). The European Commission also published in a press communicate 366/2011, the CSR Green Paper, which encourages and stimulates companies to adopt the social responsibility as part of their organizational culture. For a deeper understanding of the concept of CSR, we must take into consideration the term of "corporation", which is by far the dominant form of the economic entity in the modern market economy.

CSR must be an attitude, a sense of responsibility of each of us from the small and insignificant gestures, to even reaching the long-term development strategies. The Social Responsibility is also the fundamental ethical principle, expressing to who and for what is a manager responsible, through his own ethical principles and aiming to meet the various social problems facing the company in the communities where it operates (Poţincu \& Poţincu, 2013).

CSR brings not only benefits for the community but is a mutually beneficial strategy according to the position adopted by the social and business partners. Conceived as the "win - win" principle, CSR is the most valuable typology strategy that can be 
adopted by companies which are supporting the community in solving problems but they create also a favorable image influencing the profit.

In the early 30s when a new reform was set up because of the monopolistic actions of the companies (gains and wages freeze), Andrew Carnegie, one of the most powerful businessmen, was involved in solving various social problems. Since 1950, the theory that a favorable image of a business is closely related to social responsibilities was developed and applied. The 60's have brought to the first line a factor of powerful influence upon the companies, namely the civil rights concerning the ecological issues etc. Between 1970-1980, the social issues have become increasingly important, strengthening the link between them and the business. During the 1990, the CSR it is generally accepted and in 2000 it becomes a very important part of the strategic management.

"The biggest challenge for a company is to identify to whom it is responsible and which are the boundaries of this responsibility" (Borţun, et al, 2011). A company survival depends on those persons under direct or indirect effects generated by the business. The stakeholders are a key element while analyzing the external environment of an organization that can positively or negatively influence it.

CSR is a term that cannot be studied without an early deep bond analysis upon the main category of professionals, namely traders, focusing our attention especially on their behavior. Among these professionals and their stakeholders, a complex relationship is creating, based on trust and mutual respect.

Această inițiativă fiind prima într-adevăr eficientă pentru mediul de afaceri românesc. Corporate Social Responsibility in Romania was incurred by the multinationals, which are currently the main drivers of CSR even now (eg Coca - Cola, known for the initiated social projects). Like any important concept, needed with a rapid assimilation, the Romanian CSR was originally imposed more like a fashion than as a result of the awareness of the all the stakeholders' needs. At the first time, the domestic companies have turned to the socially responsible practices aiming to be in line with the business standards already consolidated at the European and international level. And then, after the Romanian market has become increasingly competitive, the domestic companies have begun to realize the potential socio economic approach for the construction of an image-building, as a prerequisite for commercial success in the medium and long terms. So, much of multinational or national companies operating in Romania made known their socially responsible practices and participate in an active exchange of experiences through a specialized site on Internet (Crăciun, 2005). This initiative is the first one really effective for the Romanian business environment.

It is necessary to define the Social Responsibility and the responsibilities components. Carroll and Buchholtz offers the following definition: "The Corporate Social Responsibility contains what the society expects from an organization in terms of economic, legal, ethical and philanthropic terms, in a particular time." (Carroll \& Buchholtz, 2000).

All these responsibilities must be simultaneously met and analyzed to provide a clear and real organizational view.

The economic responsibility is the most important, finding itself at the base of Carrol and Buchholtz's pyramid responsibilities. It is the guide for the all other responsibilities, keeping the economic operator on the market, the life of several categories of people such as shareholders, employees and customers depending on. The legal responsibility supposes the compliance with the legislation in force. Businesses must operate in accordance with legal regulations.

The ethical responsibilities represent the business and organizations moral behavior face to the stakeholders, all these rules being not included in the common law. 
The philanthropic responsibility is voluntary, without any external constraint and looks upon the involvement in actions meaning to improve the employees', the local communities and the community as a whole life quality. Philanthropic activities are not involving legal obligations, but it is required even a legal sanction of the economic operator, in case of failure to comply the consumer's protection legislation The difference between a philanthropic action coming from a firm and the one coming from an individual is quite visible. A philanthropic action coming from a firm is made in order to promote the main image, an individual, instead, when he making such a gesture, he has no hidden interest, without expecting anything in return. Love of the human kind, which underlies philanthropy, is replaced by a reciprocal relationship where everyone involved have something to gain.

All these types of responsibilities can be found in the business European context, but in a different approach. In the U.S., the economic responsibility is focused on achieving profit and manifests as certain strict obligations to the shareholders. This time, it is the legal responsibility that lies at the bottom of the responsibilities and the State plays a strong role in regulating the corporate activities. From the European perspective, even if the economic and the legal responsibility are remarkable, there are doubts about the ethical issues. Even for the large companies, the morality is always a controversial subject. The philanthropic responsibility was implemented due to legal regulations, taxes paid were large and the issues relating to education and those concerning the community needs remained for the Government service.

The Corporate Social Responsibility is the contribution that companies must have to support the development of the society. Between a company profitability and the social responsibility there is a mutual relationship, they are strongly influencing each other. A company that engages social works for the society is better perceived, its revenues record a increasing trend; meanwhile a company that has unlimited income can afford to promote a responsible behavior, strengthening its positive image.

The Social Responsibility is a mutually beneficial relationship between companies and communities. On the one hand, it generates a profit growth for companies, on the other hand, CSR is considered as a support for vulnerable communities or social groups. The company investments in community, as involvement activities, suppose an inputs and outputs analyze thereof. The inputs may be: the time (number of paid hours of the employees involved in CSR programs), the financial situation (the invested money), revenues in kind (benefits in kind: products, equipment, services, facilities offered by the company for the involvement in community activities), time management (how much worth the management time invested in community projects). Outputs concern: company benefits (such as reduced absenteeism, fluctuations staff, improved reputation), community benefits (how many children or how many families have daily access to a cleansing center or the cleaning up the river sides etc.), additional support or additional support value, generated by the company's initiative (the value of the City Hall involvement or the involvement of other partners, the additional funding raised by a NGO partner etc.).

The desire of companies to modernize the communities infrastructures through social, cultural or educational activities directly contribute to the increasing living standards. Thus, a greater number of people will be able to buy products or services these companies offer. New customers will be attracted by those companies contributing to the prosperity in the society they live. By interacting and long-term relationship establishing with the local authorities, a company and facilitates the understanding and a good relationship with the community residents. 


\section{Empirical observations and discusssions.}

If built correctly, the Social Responsibility may bring many advantages for a company: increase market share; enhances reputation; increase brand loyalty; attract and retain valuable employees. However, the CSR is mutually beneficial, based on the principle of "win-win". Thus, companies create a better image by influencing the profit and the involved community groups have some support in solving social problems.

All the Romanian companies agree that CSR must be assumed by businesses, but it is not right to interprete it just only like philanthropy the Social Responsibility is, broadly, a set of actions that companies do beyond their financial obligations. Currently, the Social Responsibility actions became parts of the strategic priorities of each company.

A generic approach to CSR include the following areas: human rights; working conditions in the chain of suppliers, but also within the company; the environmental impact of processes, operations, products and services; responsible investments; the impact on the local community processes, operations, products and services.

The Social Responsibility practiced by the Romanian companies have two dimensions, such as: internal and external dimensions.

Regarding the internal side, the Social Responsibility was focused on two main issues:

Adopting responsible procedures for the employees problems, problems derived referring to human capital investments, change management, safety and security at work.

The adoption of the best environmental practice, the main question arising is provided by the environmental resources management and their use in the operating system.

Human resources management. The major challenge for many companies is attracting and keeping highly qualified employees. Thus, CSR can include various measures such as providing employees decision-making power, stimulation of the lifelong learning, equal payment and career opportunities for minorities and women, better information throughout the company.

Safety in the workplace. This is the subject of numerous legal regulations, but governments and businesses seek additional ways to promote it, using these aspects as criteria for procurement of goods and services. Voluntarily applied, these arrangements may be seen as a complement to the legislative and control activities.

Environmental impact management. This size is based on the idea that the environmental impact can be reduced by reducing resource consumption, reduce waste and emissions. Therefore, we conclude that less or more efficient use of resources leads to both increased profitability and competitiveness.

Adapting to change. The contemporary European economy faced important structural changes which have affected not only employees, but also other interested stakeholders, mainly due to the closure of certain production facilities. These changes were associated with a employment decreasing trend in Europe, which involved the economic, political or social crisis, from the national to the local communities. Romanian companies must assume their part of responsibility for ensuring a certain degree of employment. They must be involved in the local development strategies and on the active labor markets, so they can reduce the impact of large-scale restructuring. The external dimensions. CSR must be extended outside the company, involving other interested social and economic groups, such as business partners - suppliers, creditors and consumers, local or central authorities, the local community or the NGOs. 
The main issues on the external dimensions of the CSR are: partnerships with business components of the markets; partnerships with the local community; the human rights protection; a greater attention for the global environment.

\section{Conclusions.}

In conclusion, we can say that the CSR takes into consideration the overall impact a company produces upon a society and the need to responsibly and specifically manage this impact on each stakeholder. When a company has a high economic performance, it can afford to devote a significant amount of its resources for social performance. Also, a large financial performance leads to a greater social performance

The aim of this paperwork is linked to the Romanian people's and businessmen need of morality, aspect becoming increasingly visible in the last decades. They are not only concerned about their own business and prosperity, but also about the welfare of the community where they are located. With their provided products and services, more and more companies gradually need to implement a policy of Social Responsibility. The company involvement, as a common citizen, has become indispensable for any economic entity wishing to obtain both the financial success and the respect of the society.

The attitude of the local or regional organization referring to those activities and responsibilities aiming the groups of interest, includes also the investments inside the community, some good customer relationships, the children's welfare and education, a support for the disadvantaged groups, a proper treatment of the environmental problems, various arts and sports funding.

Finally, the innovation is the primary factor the CSR is based on.

\section{References}

Borțun, D., Crișan, C., Dehelean, D., Ducu, C., Grigore, G., Horia, C., Oprea, L., Stancu, A., (2011) Parteneriate sustenabile și bune practici în responsabilitatea socială, București, pag. 49.

Bowen, H.R., (1953), Social Responsibilities of the Businessman, Harper \& Row, New York, NY.

Caroll, A., B., Buchholtz, A., K., (2000), Business \& Society, Ethics and Stakeholder Management, South-Western Publishing, Cinn., Ohio.

Crăciun, D., (2005), Etică în afaceri, Editura ASE, București.

Ferrel et al, (2000), Business Ethics: Ethical Decision Making and Cases, $4^{\text {th }}$ Edn. Boston: Houghton Mifflin, pag.13.

Frunză,S., (2011), Comunicare, etică și responsabilitate socială, Editura Tritonic, București, pag. 128.

Poţincu, L., Poțincu C.R., (2013), Etică în afaceri și responsabilitate socială corporatistă, Editura C.H. Beck, București, pag. 18.

http://www.wbcds.org-World Business Council for Sustainable Development. 